\title{
Exploring the Therapeutic Effects of Surya-Nadi Pranayama on Metabolic Fitness (Metf) and Bone Integrity
}

\author{
Baljinder Singh Bal \\ Department of Physical Education, Guru Nanak Dev University, Amritsar, India \\ Tel: 91-828-492-1150_E-mail: bal_baljindersingh@yahoo.co.in
}

Received: December 12, 2015 Accepted: January 25, 2016 Published: January 28, 2016

doi: 10.5296/elr.v2i1.8714 URL: http://dx.doi.org/10.5296/elr.v2i1.8714

\begin{abstract}
The primary aim of this research was to determine the therapeutic effects of Surya-Nadi Pranayama on Metabolic Fitness (MetF) and Bone Integrity. Forty Two, university level girls between the age group of 21-26 years were selected. The subjects were purposively assigned into two groups: Group-A: Experimental $\left(\mathrm{n}_{1}=21\right)$; Group-B: Control $\left(\mathrm{n}_{2}=21\right)$. The subjects from Group-A: Experimental were subjected to a 4-weeks Surya-nadi pranayama. Student $\mathrm{t}$ test for paired samples was utilized to compare the means of the pre-test and the post-test. Based on the analysis of the results obtained, we conclude that the significant differences were found in Metabolic Fitness (MetF) (i.e., Maximal Oxygen Consumption ( $\left.\mathrm{V}_{\mathrm{O} 2} \mathrm{max}\right)$ of University Level Girls. Insignificant between-group differences were noted in Blood Lipid, Blood Pressure, Blood Sugar and Bone Integrity of University Level Girls.
\end{abstract}

Keywords: Surya-Nadi Pranayama, Metabolic fitness, Bone integrity

\section{Introduction}

Yoga is a psycho-somatic-spiritual discipline for acquiring union and harmony between our mind, body, and soul and the ultimate union of our individual consciousness with the universal consciousness (Madanmohan et al., 2008). Pranayama is derived from two Sanskrit words, namely, prana, which means vital force or life energy, ayama means to prolong (Tandon, 2012). In an interventional research involving 98 subjects found fasting blood sugar (FBS), serum total cholesterol, low density lipoproteins (LDL), very low density lipoproteins (VLDL), the ratio of total cholesterol to HDL-C, and total triglycerides were significantly lower, and HDL-C significantly higher (Bijlani et al., 2005). Pranayama practices, stretches the lung tissue producing inhibitory signals from action of slowly adapting receptors and 
hyperpolarising currents (Jerath et al., 2006). Pranayama has been researched mostly for its beneficial applications in treatment of cardiovascular diseases such as hypertension (Chodzinski, 2000; Harinath, 2004), pulmonary disease such as asthma (Cooper, 2003; Vedanthan, 1998), autonomic nervous system imbalances (Pal et al. 2004), and psychologic or stress related disorders (Harinath, 2004; Brown et al., 2005). Pranayama may also affect the immune system. Inhibition of the sympathetic nervous system has been shown to enhance function of the immune system in several forms of meditation including mindfulness meditation and Transcendental meditation (Collins \& Dunn, 2005; Takahashi, 2005). The effect of different pranayamas on healthy (Subbalakshmi et al., 2005) and diseased people (Cooper et al., 2003; Dhungel et al., 2008; Ravindra \& Madanmohan, 2006) has been well studied and they are known to affect the cardiopulmonary activities and autonomic functions. Growing number of evidences have claimed that yoga practices increases longevity, (Bharshankar et al., 2003) has therapeutic (Khanam et al., 1996) and rehabilitative effects (Katiyar et al., 2006). Breathing exercises have been recommended in physiotherapy to improve respiratory and bowel function, in occupational therapy to facilitate spiritual emergence. It has been assumed single nostril breathing can be used to therapeutically influence autonomic function and may significantly affect other hemisphere- specific functions (Chanavirut, 2008). It is thought that practicing yoga over a period of time leads to a decrease in respiratory rate, muscular relaxation along with calming of the mind, which might be interpreted at least partly as a decreased state of arousal (Maharishi, 1969; Nagendra, 1977).

\section{Methods}

\subsection{Participants}

Forty Two, university level girls between the age group of 21-26 years were selected. The subjects were purposively assigned into two groups: Group-A: Experimental $\left(\mathrm{n}_{1}=21\right)$; Group-B: Control $\left(\mathrm{n}_{2}=21\right)$.

Table 1. Distribution and demographics of subjects

\begin{tabular}{llll}
\hline \multicolumn{2}{l}{ Sample Size $(\mathrm{N}=42)$} & & \\
\hline Variables & Total $(\mathrm{N}=42)$ & Experimental group $\left(\mathrm{n}_{1}=21\right)$ & Control group $\left(\mathrm{n}_{2}=21\right)$ \\
\hline Age & $21.714 \pm 1.851$ & $21.714 \pm 2.003$ & $21.714 \pm 1.736$ \\
Body Height & $5.430 \pm 1.584$ & $5.428 \pm 1.677$ & $5.433 \pm 1.527$ \\
Body Mass & $54.659 \pm 2.617$ & $54.085 \pm 2.830$ & $55.233 \pm 2.311$ \\
\hline
\end{tabular}

\subsection{Procedure}

This study is designed as a retrospective cross-sectional study. The subjects from Group-A: Experimental were subjected to a 4-weeks training of Surya-nadi Pranayama. This lasted 4 weeks and consisted of daily sessions.

- Maximal oxygen uptake (VO2max) was used as a measure of cardiopulmonary fitness and was assessed by a maximal running test on a treadmill. Maximal oxygen uptake was scaled relative to body weight $\left(\mathrm{mL} \cdot \mathrm{min}^{-1 . \mathrm{kg}-2 / 3}\right)$. 


\section{Macrothink \Institute ${ }^{\text {Im }}$}

- Blood samples $(10 \mathrm{ml})$ for the determination of lipid profiles were obtained. All of biochemical tests have been done with serum samples.

- Blood pressure was measured in supine posture by Sphygmomanometer. Two reading were taken 5 minutes apart and the mean of two was taken as the basal blood pressure.

- The blood sugar levels were measured by Digital Glucometer (ACCU-CHEK, Sr no-GN20606850 manufactured by Roche Diagnostics India Pvt. Ltd, Mumbai).

- Bone mineral density (BMD) of lumbar spine (L2-L4) in anteroposterior view was measured by dual-energy X-ray absorptiometry (DXA) using a Hologic QDR 1500W (Bedford, MA, USA).

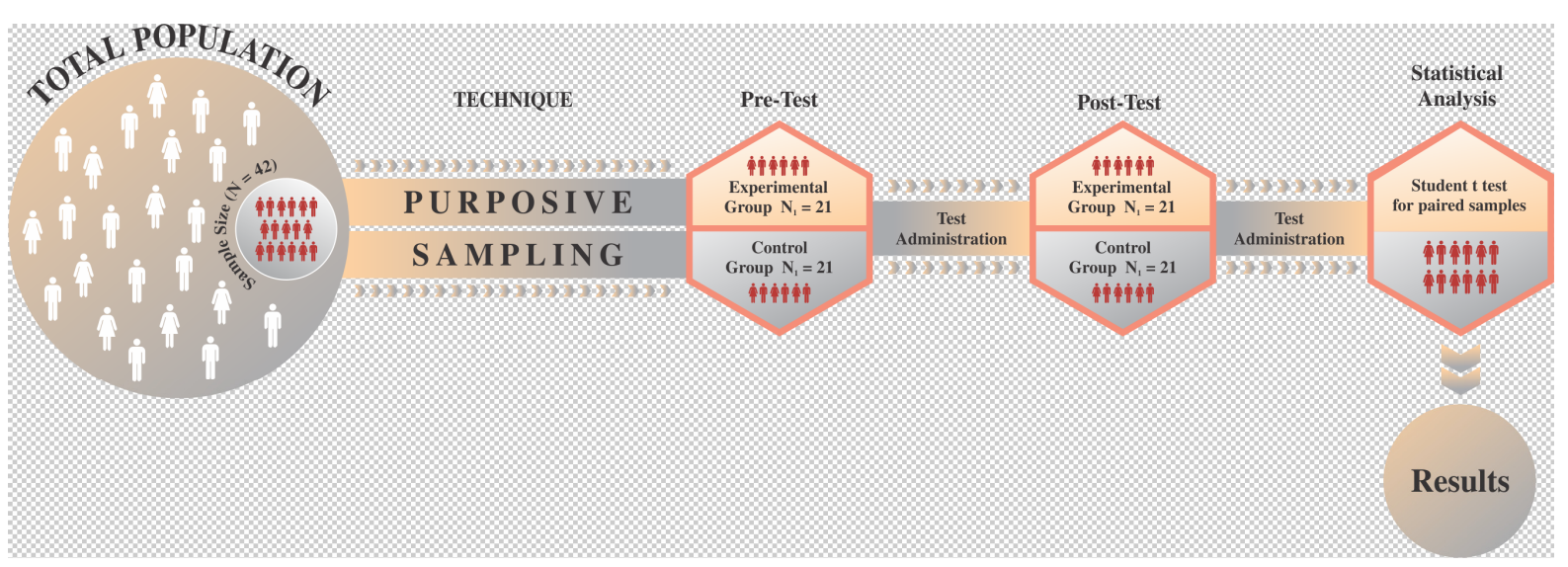

Figure 1. Study design

Table 2. Experimental treatment

4-Weeks

Surya-Nadi Pranayama Training Programme

\begin{tabular}{|c|c|c|c|}
\hline Weeks & Schedule & Time & Duration \\
\hline \multirow[t]{4}{*}{$\mathrm{I}^{\mathrm{st}}$ Week } & Preliminary Yogic Exercises & 5 Minute & \\
\hline & Practice of Surya-Nadi Pranayama & 10 Minute & \\
\hline & (9 Rounds X 1 Set) & & 20 Minute \\
\hline & Relaxation Posture & 5 Minute & \\
\hline \multirow[t]{3}{*}{$2^{\text {nd }}$ Week } & Preliminary Yogic Exercises & 5 Minute & \\
\hline & $\begin{array}{l}\text { Practice of Surya-Nadi Pranayama } \\
\text { (9 Rounds X } 2 \text { Set) }\end{array}$ & 15 Minute & 25 Minute \\
\hline & Relaxation Posture & 5 Minute & \\
\hline \multirow[t]{3}{*}{$3^{\text {rd }}$ Week } & Preliminary Yogic Exercises & 5 Minute & \\
\hline & $\begin{array}{l}\text { Practice of Surya-Nadi Pranayama } \\
\text { (9 Rounds X } 3 \text { Set) }\end{array}$ & 20 Minute & 30 Minute \\
\hline & Relaxation Posture & 5 Minute & \\
\hline \multirow[t]{3}{*}{$4^{\text {rd }}$ Week } & Preliminary Yogic Exercises & 5 Minute & \\
\hline & $\begin{array}{l}\text { Practice of Surya-Nadi Pranayama } \\
\text { (9 Rounds X } 4 \text { Set) }\end{array}$ & 25 Minute & 35 Minute \\
\hline & Relaxation Posture & 5 Minute & \\
\hline
\end{tabular}




\section{MInstitute Mank}
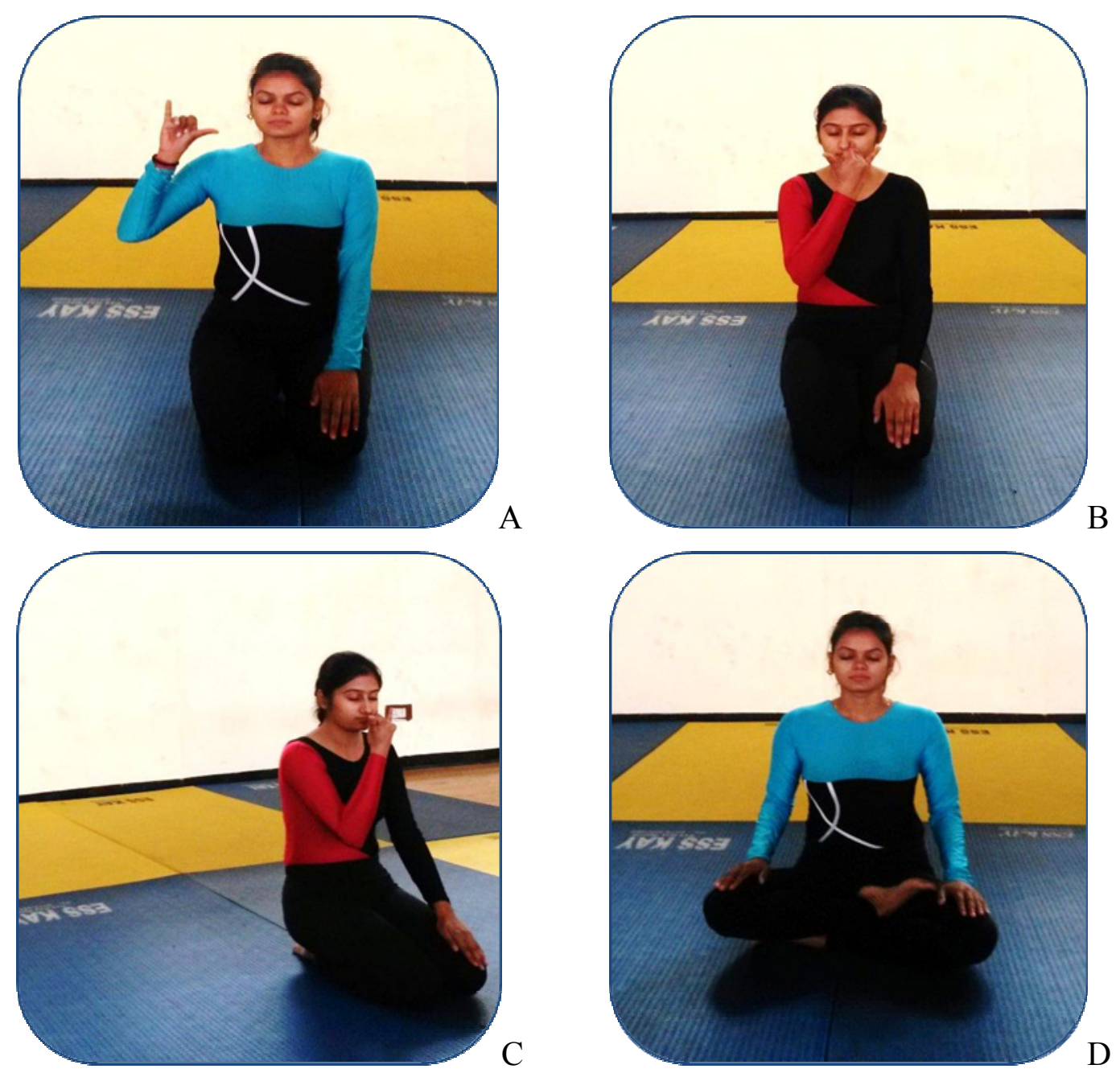

Figure 2. Subjects performing Surya Nadi Pranayama

\section{Statistical Analysis}

One Way Analysis of Variance (ANOVA) was employed to compare the three groups of basketball. For testing the hypotheses, the level of significance was set at 0.05 . 


\section{Results}

Table 3. Mean values $( \pm \mathrm{SD})$ and Paired Sample t-test of Metabolic Fitness (MetF) (i.e., Maximal Oxygen Consumption ( $\left.\mathrm{V}_{\mathrm{O} 2} \mathrm{max}\right)$, Blood Lipid, Blood Pressure and Blood Sugar) in Experimental and Control group ( $\mathrm{n}=21$ each) before (Pre) and after (Post) 4-weeks Surya Nadi Pranayama Training Programme (Experimental group only)

\begin{tabular}{lllllll}
\hline Parameters & & Group & Pre-Test & Post-Test & t-value & p-value \\
\hline Maximal & \multicolumn{1}{c}{ Oxygen } & Experimental & $33.69 \pm 2.21$ & $34.78 \pm 1.52$ & $5.931 *$ & 0.0001 \\
Consumption $\left(\mathrm{V}_{\mathrm{O} 2 \mathrm{max}}\right)$ & Control & $22.66 \pm 0.45$ & $22.48 \pm 0.28$ & 1.806 & 0.0859 \\
& Cholesterol & Experimental & $153.02 \pm 11.46$ & $153.32 \pm 11.24$ & 1.468 & 0.1574 \\
Blood & & Control & $157.81 \pm 9.98$ & $157.86 \pm 10.01$ & 1.105 & 0.2821 \\
Lipid & Triglycerides & Experimental & $146.64 \pm 1.87$ & $146.72 \pm 1.72$ & 0.782 & 0.4430 \\
& & Control & $135.16 \pm 8.65$ & $135.18 \pm 8.64$ & 0.721 & 0.4787 \\
& Systolic Blood & Experimental & $111.33 \pm 3.55$ & $111.67 \pm 3.35$ & 1.581 & 0.1295 \\
Blood & Pressure & Control & $125.90 \pm 3.39$ & $126.29 \pm 2.33$ & 0.477 & 0.6379 \\
Pressure & Diastolic & Experimental & $83.62 \pm 2.58$ & $84.29 \pm 1.71$ & 1.071 & 0.2968 \\
& Blood & Control & $76.10 \pm 2.14$ & $76.24 \pm 1.87$ & 0.568 & 0.5764 \\
& Pressure & & & & & \\
& Fasting Blood & Experimental & $85.62 \pm 2.82$ & $86.86 \pm 3.29$ & 1.618 & 0.1212 \\
Blood & Sugar & Control & $95.38 \pm 2.64$ & $96.29 \pm 3.24$ & 0.948 & 0.3540 \\
Sugar & Post Prandial & Experimental & $124.33 \pm 3.12$ & $125.67 \pm 2.82$ & 1.122 & 0.2750 \\
& Blood Sugar & Control & $133.90 \pm 3.90$ & $134.86 \pm 2.94$ & 0.779 & 0.4448 \\
\hline
\end{tabular}

*Significantly $(\mathrm{p}<0.001)$ different from the respective 'Pre' value.

\subsection{Maximal Oxygen Consumption ( $V_{O 2} \max$ )}

The results of Metabolic Fitness (MetF) in group (Experimental) and group (Control) are shown in Table-3. The Mean and Standard Deviation $( \pm \mathrm{SD})$ values of Maximal Oxygen Consumption $\left(\mathrm{V}_{\mathrm{O} 2} \mathrm{max}\right)$ of pre-test and post-test of experimental group were $33.69 \pm 2.21 \&$ $34.78 \pm 1.52$ respectively. However, the Mean and Standard Deviation $( \pm S D)$ values of Maximal Oxygen Consumption $\left(\mathrm{V}_{\mathrm{O} 2} \mathrm{max}\right)$ of pre-test and post-test of control group were $22.66 \pm 0.45 \& 22.48 \pm 0.28$. The t-value in case of experimental group was 5.931 *and for control group it was 1.806 .

Significant between-group differences were noted in Maximal Oxygen Consumption $\left(\mathrm{V}_{\mathrm{O} 2} \mathrm{max}\right)$ in the experimental group before (Pre) and after (Post) subjected to 4-weeks Surya Nadi Pranayama Training Programme since, the calculated value of $\left(\mathrm{t}=5.931^{*}\right)$ is greater than tabulated value of $t .05(20)=2.09$ for the selected degree of freedom and level of significance. However, no significant changes over that 4- week period were noted in the control group.

\subsection{Cholesterol}

The Mean and Standard Deviation values $( \pm \mathrm{SD})$ of Cholesterol of pre-test and post-test of experimental group were $153.02 \pm 11.46$ and $153.32 \pm 11.24$ respectively. However, the Mean and Standard Deviation ( $\pm \mathrm{SD}$ ) values of Cholesterol of pre-test and post-test of control group were $157.81 \pm 9.98$ and $157.86 \pm 10.01$. The $t$-value in case of experimental group was 1.468 and for control group it was 1.105 . 
Insignificant between-group differences were noted in Cholesterol in the experimental group before (Pre) and after (Post) subjected to 4-weeks Surya Nadi Pranayama Training Programme since, the calculated value of $(t=1.468)$ is less than tabulated value of $t_{05}(20)=$ 2.09 for the selected degree of freedom and level of significance. However, no significant changes over that 4- week period were noted in the control group.

\subsection{Triglycerides}

The Mean and Standard Deviation values ( \pm SD) of Triglycerides of pre-test and post-test of experimental group were $146.64 \pm 1.87$ and $146.72 \pm 1.72$ respectively. However, the Mean and Standard Deviation $( \pm \mathrm{SD})$ values of Triglycerides of pre-test and post-test of control group were $135.16 \pm 8.65$ and $135.18 \pm 8.64$. The t-value in case of experimental group was 0.782 and for control group it was 0.721 .

Insignificant between-group differences were noted in Triglycerides in the experimental group before (Pre) and after (Post) subjected to 4-weeks Surya Nadi Pranayama Training Programme since, the calculated value of $(\mathrm{t}=0.782)$ is less than tabulated value of $\mathrm{t}_{05}(20)=$ 2.09 for the selected degree of freedom and level of significance. However, no significant changes over that 4- week period were noted in the control group.

\subsection{Systolic Blood Pressure}

The Mean and Standard Deviation $( \pm \mathrm{SD})$ values of Systolic Blood Pressure of pre-test and post-test of experimental group were $111.33 \pm 3.55 \& 111.67 \pm 3.35$ respectively. However, the Mean and Standard Deviation $( \pm \mathrm{SD})$ values of Systolic Blood Pressure of pre-test and post-test of control group were $125.90 \pm 3.39 \& 126.29 \pm 2.33$. The $t$-value in case of experimental group was 1.581 and for control group it was 0.477 .

Insignificant between-group differences were noted in Systolic Blood Pressure in the experimental group before (Pre) and after (Post) subjected to 4-weeks Surya Nadi Pranayama Training Programme since, the calculated value of $(\mathrm{t}=1.581)$ is greater than tabulated value of $\mathrm{t} .05(20)=2.09$ for the selected degree of freedom and level of significance. However, no significant changes over that 4- week period were noted in the control group.

\subsection{Diastolic Blood Pressure}

The Mean and Standard Deviation $( \pm \mathrm{SD})$ values of Diastolic Blood Pressure of pre-test and post-test of experimental group were $83.62 \pm 2.58 \& 84.29 \pm 1.71$ respectively. However, the Mean and Standard Deviation $( \pm \mathrm{SD})$ values of Diastolic Blood Pressure of pre-test and post-test of control group were $76.10 \pm 2.14 \& 76.24 \pm 1.87$. The t-value in case of experimental group was 1.071 and for control group it was 0.568 .

Insignificant between-group differences were noted in Diastolic Blood Pressure in the experimental group before (Pre) and after (Post) subjected to 4-weeks Surya Nadi Pranayama Training Programme since, the calculated value of $(\mathrm{t}=1.071)$ is greater than tabulated value of $t .05(20)=2.09$ for the selected degree of freedom and level of significance. However, no significant changes over that 4- week period were noted in the control group.

\subsection{Fasting Blood Sugar}

The Mean and Standard Deviation $( \pm \mathrm{SD})$ values of Fasting Blood Sugar of pre-test and post-test of experimental group were $85.62 \pm 2.82 \& 86.86 \pm 3.29$ respectively. However, the Mean and Standard Deviation $( \pm \mathrm{SD})$ values of Fasting Blood Sugar of pre-test and post-test 
of control group were $95.38 \pm 2.64 \& 96.29 \pm 3.24$. The t-value in case of experimental group was 1.618 and for control group it was 0.948 .

Insignificant between-group differences were noted in Fasting Blood Sugar in the experimental group before (Pre) and after (Post) subjected to 4-weeks Surya Nadi Pranayama Training Programme since, the calculated value of $(\mathrm{t}=1.618)$ is less than tabulated value of $\mathrm{t}_{.05}$ $(20)=2.09$ for the selected degree of freedom and level of significance. However, no significant changes over that 4- week period were noted in the control group.

\section{7 Post Prandial Blood Sugar}

The Mean and Standard Deviation $( \pm \mathrm{SD})$ values of Post Prandial Blood Sugar of pre-test and post-test of experimental group were $124.33 \pm 3.12 \& 125.67 \pm 2.82$ respectively. However, the Mean and Standard Deviation $( \pm \mathrm{SD})$ values of Post Prandial Blood Sugar of pre-test and post-test of control group were $133.90 \pm 3.90 \& 134.86 \pm 2.94$. The t-value in case of experimental group was 1.122 and for control group it was 0.779 .

Insignificant between-group differences were noted in Post Prandial Blood Sugar in the experimental group before (Pre) and after (Post) subjected to 4-weeks Surya Nadi Pranayama Training Programme since, the calculated value of $(\mathrm{t}=1.122)$ is less than tabulated value of $\mathrm{t}_{.05}$ $(20)=2.09$ for the selected degree of freedom and level of significance. However, no significant changes over that 4- week period were noted in the control group.

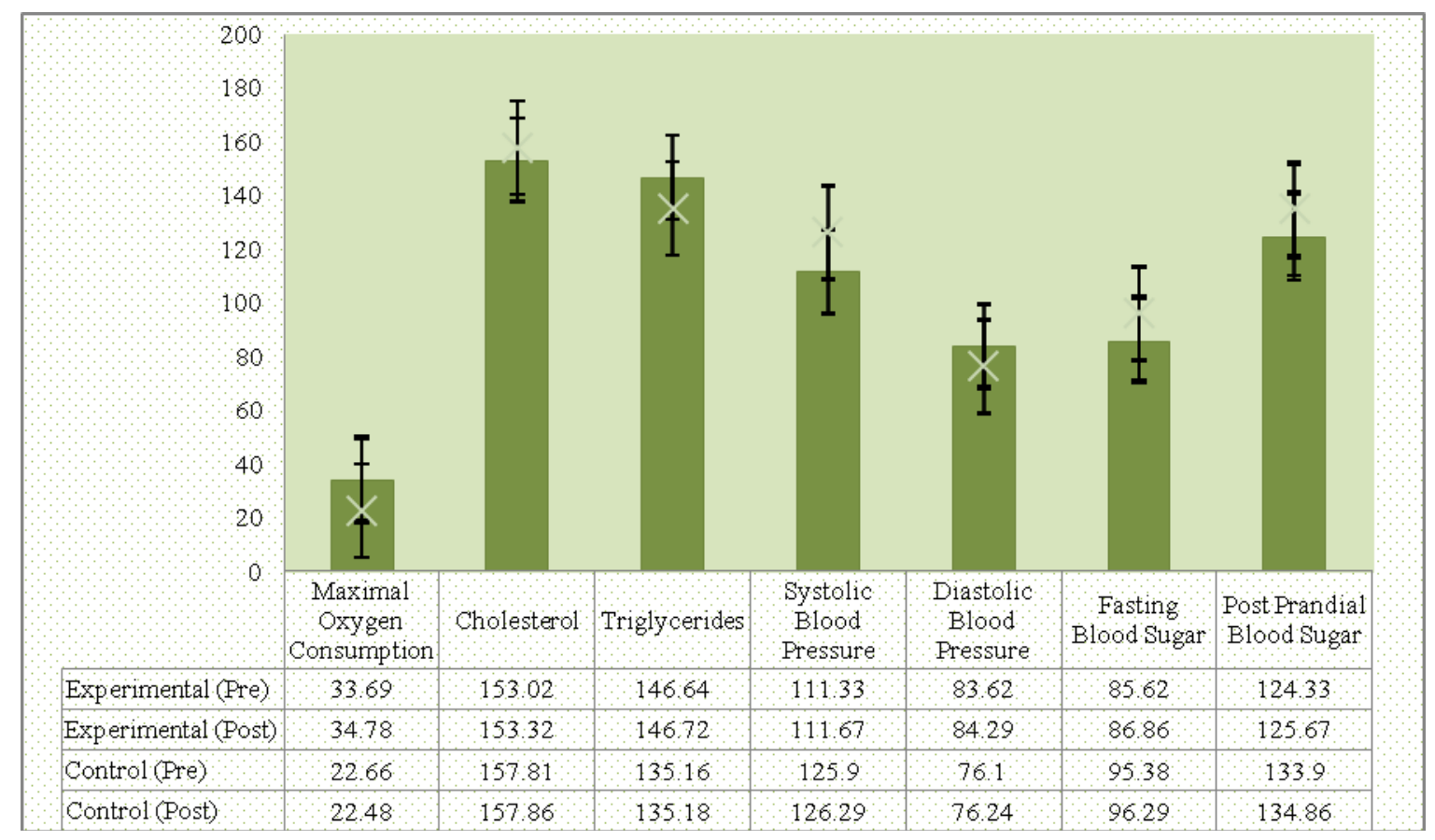

Figure 3. Mean values of Metabolic Fitness (MetF) (i.e., Maximal Oxygen Consumption ( $\mathrm{V}_{\mathrm{O} 2} \mathrm{max}$ ), Blood Lipid, Blood Pressure and Blood Sugar) in Experimental and Control group $(n=21$ each) before (Pre) and after (Post) 4-weeks Surya Nadi Pranayama Training Programme (Experimental group only) 
Table 4. Mean values $( \pm \mathrm{SD})$ and Paired Sample t-test of Bone Integrity in Experimental and Control group ( $\mathrm{n}=21$ each) before (Pre) and after (Post) 4-weeks Surya Nadi Pranayama Training Programme (Experimental group only)

\begin{tabular}{llllll}
\hline Parameters & Group & Pre-Test & Post-Test & t-value & p-value \\
\hline Bone Integrity & Experimental & $1.13 \pm 0.021$ & $1.12 \pm 0.008$ & 1.700 & 0.1046 \\
& Control & $1.13 \pm 0.016$ & $1.13 \pm 0.014$ & 0.256 & 0.8000 \\
\hline
\end{tabular}

*Significantly $(\mathrm{p}<0.001)$ different from the respective 'Pre' value.

\subsection{Bone Integrity}

The Mean and Standard Deviation $( \pm \mathrm{SD})$ values of Bone Integrity of pre-test and post-test of experimental group were $1.13 \pm 0.021 \& 1.12 \pm 0.008$ respectively. However, the Mean and Standard Deviation $( \pm \mathrm{SD})$ values of Bone Integrity of pre-test and post-test of control group were $1.13 \pm 0.016 \& 1.13 \pm 0.014$. The t-value in case of experimental group was 1.700 and for control group it was 0.256 .

Insignificant between-group differences were noted in Bone Integrity in the experimental group before (Pre) and after (Post) subjected to 4-weeks Surya-Nadi Pranayama Training Programme since, the calculated value of $(t=1.7)$ is less than tabulated value of $t_{.05}(20)=2.09$ for the selected degree of freedom and level of significance. However, no significant changes over that 4- week period were noted in the control group.

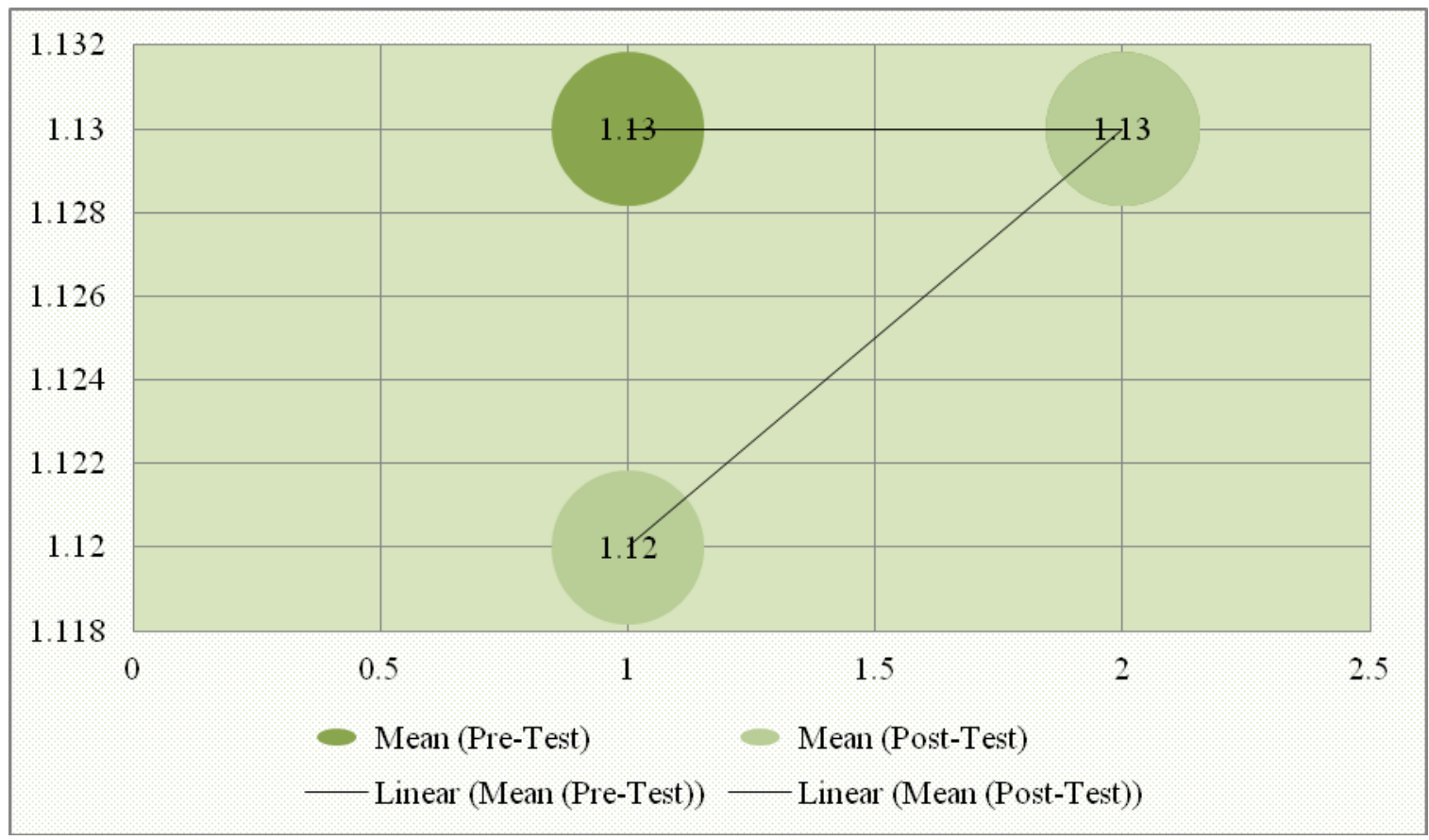

Figure 4. Mean values of Bone Integrity in Experimental and Control group ( $\mathrm{n}=21$ each) before (Pre) and after (Post) 4-weeks Surya Nadi Pranayama Training Programme (Experimental group only)

\section{Conclusions}

Based on the analysis of the results obtained, we conclude that the significant differences 
were found in Metabolic Fitness (MetF) (i.e., Maximal Oxygen Consumption ( $\mathrm{V}_{\mathrm{O} 2} \mathrm{max}$ ) of University Level Girls. Insignificant between-group differences were noted in Blood Lipid, Blood Pressure, Blood Sugar and Bone Integrity of University Level Girls.

\section{References}

Chodzinski, J. (2000). The effect of rhythmic breathing on blood pressure in hypertensive adults. $J$ Undergrad Res, 1(6).

Harinath, K. (2004). Effects of Hatha yoga and Omkar meditation on cardiorespiratory performance, psychologic profile, and melatonin secretion. J Altern Complement Med, 10(2), 261-8. http://dx.doi.org/10.1089/107555304323062257

Cooper, S. (2003). Effect of two breathing exercises (Buteyko and pranayama) in asthma: a randomised controlled trial. Thorax, 58(8), 674-9. http://dx.doi.org/10.1136/thorax.58.8.674

Vedanthan, P. (1998). Clinical study of yoga techniques in university students with asthma: a controlled study. Allergy Asthma Proc, $19(1), \quad 3-9$. http://dx.doi.org/10.2500/108854198778557971

Pal, G., Velkumary, S., \& Madanmohan. (2004). Effect of short-term practice of breathing exercises on autonomic functions in normal human volunteers. Indian J Med Res, 120(2), 115-21.

Brown, R., \& Gerbarg, P. (2005). Sudarshan Kriya Yogic breathing in the treatment of stress, anxiety, and depression: part II-clinical applications and guidelines. J Altern Complement Med, 11(4), 711-7. http://dx.doi.org/10.1089/acm.2005.11.711

Jerath, R. J., Edry, V. A., Barnes, V. A., \& Jerath, V. (2006). Physiology of long pranayamic breathing: Neural respiratory elements may provide a mechanism that explains how slow breathing shifts the autonomic nervous system. Med Hypotheses, 67, 566-71. http://dx.doi.org/10.1016/j.mehy.2006.02.042

Bijlani, R. L., Vempati, R. P., Yadav, R. K., Ray, R. B., Gupta, V., \& Sharma, R. (2005). A brief but comprehensive lifestyle education program based on yoga reduces risk factors for cardiovascular disease and diabetes mellitus. J Altern Complement Med, 11, 267-74. http://dx.doi.org/10.1089/acm.2005.11.267

Madanmohan, Mahadevan, S. K., Balakrishnan, S., Gopalakrishnan, M., \& Prakash, E. S. (2008). Effect of 6 wks yoga training on weight loss following step test, respiratory pressures, handgrip strength and handgrip endurance in young healthy subjects. Indian J Physiol Pharmacol, 52, 164-70.

Tandon, O. P. (2012). Yoga and its applications. In O. P. Tandon, \& Y. Tripathi (Eds.), Best and Taylor's Physiological Basis of Medical Practice (13th ed.) Gurgaon: Wolters Kluwer health/Lippincott Williams and Wilkins publishers, 1217-30.

Collins, M., \& Dunn, L. (2005). The effects of meditation and visual imagery on an immune system disorder: dermatomyositis. $J$ Altern Complement Med, 11(2), 275-84. http://dx.doi.org/10.1089/acm.2005.11.275

Takahashi, T. (2005). Changes in EEG and autonomic nervous activity during meditation and their association with personality traits. Int $J$ Psychophysiol, 55(2), 199-207. http://dx.doi.org/10.1016/j.ijpsycho.2004.07.004 


\section{Al Macrothink

Subbalakshmi, N. K., Saxena, S. K., Urmimala, D., \& Urban, J. A. (2005). Immediate effect of Nadishodhan Pranayama on some selected parameters of cardiovascular, pulmonary and higher functions of brain. Thai J Physiological Sciences, 18, 10-16.

Cooper, S., Oborne, J., Newton, S., Harrison, V., Thompson, C. J., Lewis, S., \& Tattersfield, A. (2003). Effect of two breathing exercises (Buteyko and pranayama) in asthma: a randomised controlled trial. Thorax, 64-75. http://dx.doi.org/10.1136/thorax.58.8.674

Dhungel, K. U., Malhotra, V., Sarkar, D., \& Prajapati, R. (2008). Effect of alternate nostril breathing exercise on cardiorespiratory functions. Nepal Med Coll J, 10, 25-27.

Ravindra, P. N., \& Madanmohan, P. P. (2006). Effect of pranayam (yogic breathing) and shavasan (relaxation training) on the frequency of benign ventricular ectopics in two patients with palpitations. Int J Cardiol, 108, 124-125. http://dx.doi.org/10.1016/j.ijcard.2005.02.023

Bharshankar, J. R., Bharshanker, R. N., Deshpande, V. N., Kaore, S. B., \& Gosavi, G. B. (2003). Effect of yoga on cardiovascular system in subjects above 40 years. Indian J Physiol Pharmacol, 47(2), 202-06.

Khanam, A. A., Sachdev, V., Guleria, R., \& Deepak, K. K. (1996). Study of pulmonary and autonomic functions of asthma patients after yoga training. Indian $J$ Physiol Pharmacol, 40(4), 318-24.

Katiyar, S. K., \& Bihari, S. (2006). Role of pranayama in rehabilitation of COPD patients - a randomized controlled study. Indian J Allergy Asthma Immunol, 20(2), 98-104.

\section{Copyright Disclaimer}

Copyright reserved by the author(s).

This article is an open-access article distributed under the terms and conditions of the Creative Commons Attribution license (http://creativecommons.org/licenses/by/3.0/). 